\title{
DISCURSOS SOBRE O FEMININO \\ Um mapeamento dos programas eleitorais de Dilma Rousseff
}

\section{Ricardo Fabrino Mendonça Ana Carolina Ogando}

\section{Introdução}

As eleições de 2010 foram marcadas por uma série de novidades se comparadas aos demais pleitos da Nova República. A ausência de Luís Inácio Lula da Silva como candidato à presidência, as discussões em torno da Lei Complementar 135/2010 ("Ficha Limpa") e a utilização de plataformas digitais por candidato(a)s e eleitore(a)s são bons exemplos de tais novidades. No entanto, a mudança que nos interessa ressaltar aqui é o protagonismo desempenhado por duas mulheres na disputa para o posto mais elevado do Executivo nacional: Dilma Rousseff (PT), como primeira mulher com chances efetivas na corrida presidencial; e Marina Silva (PV), como candidata capaz de se interpor entre governo e oposição, angariando os votos de significativas parcelas da população. Essa forte presença de mulheres nas eleiçôes presidenciais colocou a questão do "feminino" em pauta, tematizando as relaçõoes entre gênero e política.

É no interior desse contexto que se torna relevante compreender como tal pauta foi discursivamente mobilizada pelo(a)s candidato(a) s. Reconhecendo que essas candidaturas são, em grande medida, moldadas pela cobertura da mídia, pela própria retórica do(a)s candidato(a)s e pelos discursos dos oponentes (Gomes, 2004; Parry-Giles, 2000), interessa-nos perceber o modo como "o feminino" foi construído nos programas televisivos das campanhas do Horário Gratuito de Propaganda Eleitoral (HGPE). Neste artigo, por razões de espaço e escopo, nosso foco volta-se exclusivamente para a campanha de Dilma Rousseff, candidata que viria a se tornar a primeira presidenta do Brasil. 
O texto divide-se em três partes. Iniciamos com uma breve discussão sobre gênero, comunicação e política, apontando argumentos críticos e favoráveis à marcação de gênero em campanhas eleitorais. Em seguida, apresentamos os procedimentos metodológicos que guiaram nossa investigação: uma análise qualitativa de enquadramento dos segmentos em que a questão de gênero emerge no HGPE de Dilma. Procuramos, sobretudo, manifestações de quatro quadros interpretativos frequentemente mobilizados pela literatura feminista: (1) discurso da igualdade; (2) marcação da diferença; (3) ética do cuidado; e (4) desconstrucionismo. Nesta parte, também buscamos delinear o contexto argumentativo mais amplo construído por Dilma e sua equipe. Na terceira e última parte do artigo, apresentamos a análise propriamente dita, dividindo-a em quatro subseçóes que definem os supracitados enquadramentos e apresentam os modos pelos quais eles se manifestam ou poderiam se manifestar.

Os achados indicam a presença da questão de gênero nas campanhas, mas, sobretudo, de uma forma tangencial. Em poucos momentos, questôes de gênero são frontalmente debatidas, o que gera enfraquecimento dos quadros da igualdade e do desconstrucionismo. A análise revela uma tentativa permanente de ressaltar o pioneirismo de Dilma em inserir-se em ambientes tipicamente masculinos. Além disso, há uma presença recorrente da ideia de uma candidata que continuará o trabalho paternal de Lula, que não pensa em números, mas em pessoas. Se, nas campanhas, Dilma não é apresentada como a mãe do PAC, algo que Lula frequentemente fazia em outras arenas discursivas, ela é tacitamente delineada como a mãe do Brasil, capaz de cuidar da nação e zelar pelo povo brasileiro. Nas considerações finais, exploramos as implicações políticas desse discurso que, tangencialmente, traz o "feminino" para o cerne da campanha política.

\section{Comunicação e política e gênero}

São raros os estudos de comunicação e política centralmente preocupados com a questão de gênero. Como bem assinalam Miguel e Biroli, embora "haja tradição consolidada de trabalho acadêmico para cada um dos pares (investigaçóes sobre gênero e política, sobre política e mídia, sobre gênero e mídia), a interseção das três temáticas ainda é um campo pouco estudado na literatura internacional e em especial no Brasil" (2011, p. 1). Alguns pesquisadores, contudo, têm buscado sanar essa lacuna.

O trabalho de Miguel e Biroli é particularmente interessante a esse respeito, evidenciando o modo como as hierarquias do campo político "guardam correlação com os padrões de visibilidade nos meios de comunicação" (Idem, p. 12). As análises dos pesquisadores indicam o reforço midiático de estereótipos de gênero e a exclusão de mulheres do papel de sujeitos do discurso. Além disso, elas são sub-representadas, o que não só reflete como também promove desigualdades existentes (Idem, p. 16).

Também merece menção o trabalho desenvolvido por Mantovani (2011) voltado à discussão do aborto em textos opinativos publicados por Globo e Folha de S. Paulo, no sentido de delinear a constituição da agenda eleitoral de 2010 . O artigo sugere a existência de um debate superficial, com predomínio de vozes masculinas e homogêneas. Outro estudo interessante é o de Cristofoletti e Watko (2009) acerca da visibilidade de mulheres negras em três jornais catarinenses. A investigação aponta para um apagamento das diferenças culturais e étnicas, bem como o reforço de estereótipos existentes.

Ainda permanecem pouco estudadas, contudo, as relações entre gênero e política nas estratégias de campanhas eleitorais. Isso não se deve meramente a uma negligência dos pesquisadores em relação à temática, mas, também, à invisibilidade das próprias mulheres na política e das questôes de gênero nas campanhas. No Brasil, por exemplo, essa questão só veio à tona, nacionalmente, nas últimas eleições presidenciais, quando duas candidatas desempenharam papel de destaque. Mesmo que algumas mulheres tenham ocupado lugar central na política regional brasileira, ${ }^{1}$ não se notam muitos estudos sistemáticos sobre a forma como elas mobilizaram a questão "do feminino" em suas campanhas. Uma exceção é o instigante artigo de Teresinha Pires sobre a construção de Dilma Rousseff como "mãe do povo brasileiro". Analisando discursos do então 
presidente Lula, o filme sobre a vida dele dirigido por Fábio Barreto e vinte programas do HGPE veiculados no primeiro turno das eleiçóes, Pires advoga que Dilma foi retoricamente construída como a continuadora do Lulismo, um jeito de governar que cuida do povo. Assim, "o epíteto Mãe do povo mostrou-se um recurso retórico - construído no interior da cultura - muito eficaz do ponto de vista político, uma estratégia sensível, capaz de apresentar o modelo de bom governo com forte apelo emocional" (Pires, 2011, p. 103).

No plano internacional, alguns estudos buscam refletir sobre a relação de estereótipos de gênero com campanhas eleitorais. Susan Carroll (2009), por exemplo, faz interessante análise da campanha presidencial de 2008 nos Estados Unidos, apontando para a existência de três estereótipos de gênero que o público expressa contra mulheres candidatas. ${ }^{2}$ Primeiro, muitos assumem que mulheres são menos qualificadas para entrar na política; segundo, existe o estereótipo de que mulheres não são fortes ou agressivas o suficiente para liderar; terceiro, afirma-se que mulheres seriam muito emotivas para lidar com questóes complexas, sendo, portanto, menos preparadas para assuntos de hard politics, como economia, segurança e política externa. ${ }^{3}$

O enfoque em estereótipos também pode passar por uma análise das diferenças presentes nas campanhas de candidatos e candidatas no que se refere ao tratamento de assuntos públicos, tons assumidos e propósitos das peças produzidas Em investigação comparando as eleições para a Câmara de Deputados nos Estados Unidos em 2000 e 2002, as autoras perceberam que a agressividade e outros traços tidos como masculinos são mais comuns em campanhas de candidatas com menos chances de vencer uma eleição e que o contexto de cada eleição influencia a adoção de estereótipos que visam a demarcar a diferença de gênero (Sapiro et al., 2009).

É importante perceber que a literatura aponta consequências variadas quanto à adoção de um estilo supostamente "feminino" de fazer política. De acordo com Shawn Parry-Giles e Terry Parry-Giles (1996, pp. 339-340), a construção de um estilo supostamente "feminino" inclui um enquadramento discursivo que se caracteriza pelo foco em: detalhes pessoais, organização em padrões indutivos e não lineares, estilização e ornamentação, dependência de anedotas e encorajamento de identificação entre falante e audiências.

Para alguns autores, tal adoção configura-se como uma estratégia criativa contra o sexismo eleitoral (Jamieson, 1995) ou mesmo como uma possibilidade de transformação profunda que estabelece uma "política feminizada" (feminized politics) (Dow e Tonn, 1993). Delinear supostas diferenças femininas seria um jeito de projetar um modo distinto de fazer política, menos agressivo e mais hábil em envolver as pessoas, confrontando a apatia política generalizada.

Para outros, contudo, a necessidade de criticar essa estratégia sobrepōe-se a seus eventuais benefícios. O malefício pode ser pragmático, na medida em que a expressão de traços tomados como femininos poderia prejudicar a campanha de uma candidata. Tanto que alguns estudos mostram que a capacidade de expressar traços tidos como masculinos é muito importante na concorrência para cargos mais elevados, como o da presidência (Huddy e Terkildsen, 1993).

Outra consequência maléfica de tal adoção é de caráter não pragmático. Parry-Giles e Parry-Giles (1996) questionam esse estilo, alertando que ele pode reforçar hierarquias de gênero e uma lógica "masculina" já dominante na política. Eles afirmam que tal discurso corre o risco de cristalizar binarismos e estereótipos ao afirmar a diferença dentro de quadros interpretativos que pasteurizam a diversidade de gênero. Essa afirmação identitária não seria fundamentalmente transformadora ao manter intactos padrōes interpretativos androcêntricos em voga (Fraser, 2003).

Diante disso, a forma como um(a) candidato(a) encaminha a questão de gênero é bastante delicada, embora muito relevante, pois a partir daí é possível tanto questionar padrões interpretativos e práticas sociais desrespeitosos, como mobilizar votos de parcelas significativas do eleitorado. Entender, pois, o modo pelo qual a primeira presidente do Brasil abordou essa questão quando candidata é algo muito interessante. Para fazê-lo, contudo, precisamos, antes, apresentar os procedimentos empregados nesse percurso. 


\section{Procedimentos metodológicos}

O estudo de campanhas do Horário Gratuito de Propaganda Eleitoral (HGPE) atrai crescente atenção de pesquisadores. No Brasil, alguns dos principais estudiosos de comunicação e política já se dedicaram a investigações de campanhas televisivas, seja para produzir análises de discurso sobre o HGPE (Albuquerque, 1999, 1995; Weber, 1996; Almeida, 1999; Chaia, 2004; Miguel, 1998, 2010; Porto e Guazina, 1999; Rubim, 2003; Rubim, Kopp e Albinati, 2004; Venturi, 1998), seja para discutir a eficácia ou os efeitos desses programas (Figueiredo e Aldé, 2010; Figueiredo, 2007; Veiga, 2003), seja ainda para abordar a dimensão mais estrutural do marketing político (Gomes, 2004; Almeida, 2002; Queiroz, 2003, 2011; Carvalho, 1998). Também há um conjunto de trabalhos voltados à discussão do HGPE de plebiscitos e referendos (Miguel, 1996; Fuks e Pacheco, 2006; Veiga e Santos, 2008; Mendonça e Santos, 2009).

$\mathrm{O}$ já clássico livro de Albuquerque classifica os estudos sobre HGPE em cinco grandes categorias:

1) investigações sobre a influência das legislações eleitorais [...] sobre a propaganda política na televisão; 2) análises das estratégias comunicativas empregadas na televisão pela campanha de um ou mais candidatos; 3) análises do processo de produção de campanhas políticas na televisão, tendo em vista o modo de atuação dos consultores de media; 4) estudos que discutem a propaganda política na televisão à luz da retórica; 5) estudos que desenvolvem ou adaptam categorias de análise para a propaganda política brasileira (Albuquerque, 1999, p. 19).

Essa literatura produziu um conjunto interessante de análises e de percursos metodológicos, sugerindo operadores diversos para finalidades distintas. Sem buscar uma revisão exaustiva desses trabalhos, este estudo pretende verificar as maneiras por meio das quais a campanha de Dilma articulou a relação entre gênero e política. Trabalhamos, especificamente, com os programas televisivos da candidata veiculados entre os dias 17 de agosto e 29 de outubro de 2010, o que engloba ambos os turnos do referido pleito. ${ }^{4}$ Os programas do primeiro turno tinham duração de dez minutos e 38 segundos; os do segundo tinham duração de dez minutos. ${ }^{5}$ Nesse momento da pesquisa, não nos dedicamos aos spots ${ }^{6}$ veiculados durante os blocos de propagandas comerciais, nem realizamos um estudo comparativo da campanha de Dilma com as de outros candidatos. ${ }^{7}$

De cunho qualitativo, a análise buscou identificar a forma como questões de gênero foram trabalhadas ao longo da campanha. Para tanto, assistimos aos programas, codificando segmentos ${ }^{8}$ que faziam referências à questão de gênero, de acordo com a seguinte grade analítica: identificação do segmento; data; turno; enquadramento; tema; quem fala; transcrição textual do trecho; observaçōes de imagem e continuidade. Inicialmente, assistimos, juntos, a oito programas, a fim de discutir a aplicação das categorias e, em seguida, cada um dos pesquisadores responsabilizou-se por um dos turnos das eleiçōes. Ao final do processo, os pesquisadores conversaram sobre eventuais dúvidas, dificuldades e arestas.

O ponto fundamental dessa análise é o mapeamento de enquadramentos por meio dos quais a questão de gênero é abordada. Os enquadramentos configuram-se como padrôes de organização por meio dos quais sujeitos interpretam e se engajam nas diferentes situações. Trata-se, em linhas gerais, de molduras de sentido que balizam a experiência, ao mesmo tempo em que emergem dela. Com base na obra de Gregory Bateson (2002), atualizadas pelo trabalho canônico de Erving Goffman (1986), o conceito tem sido operacionalizado por uma diversidade de estudos (Weaver, 2007; Reese, 2007; Van Gorp, 2007; D’Angelo, 2002).

Não é nosso intuito, aqui, discorrer acerca das diferentes abordagens e operacionalizaçôes do conceito. ${ }^{9}$ Vale ressaltar, contudo, que não empregamos o conceito como sinônimo de temas, nem buscamos mensurar os chamados efeitos cognitivos do framing, como alguns pesquisadores têm feito. Nossa opção por este conceito deve-se a seu potencial para a realização de estudos qualitativos e está fortemente assentada na ideia de que quadros não são um viés construído pelo sujeito. Quadros são pacotes interpretativos (Gamson e Modigliani, 1989), enraizados culturalmente (Van Gorp, 2007) e pro- 
duzidos em interação (Goffman, 1986; Steinberg, 1998). Não são construçōes individuais, embora sejam mobilizados por indivíduos, consciente ou inconscientemente, em sua permanente atividade de dotar o mundo de significação.

Com base nessa visão, partimos da literatura sobre gênero e política para sugerir quatro enquadramentos fundamentais: (1) discurso da igualdade; (2) marcação da diferença; (3) ética do cuidado; e (4) desconstrucionismo. ${ }^{10}$ Mesmo que haja pontos de sobreposição e de articulação entre tais quadros, cada um deles explora a questão "do feminino" a partir de uma ótica distinta. Tais quadros atribuem causas diferentes à existência de práticas desrespeitosas, delineiam problemas morais de ordem distinta e prescrevem soluções diversas para a superação de tais problemas. ${ }^{11}$

A apresentação dos achados dessa investigação é guiada por tais quadros. Expomos as formas como cada um deles se manifesta, insinua-se ou não se faz presente nos programas do HGPE de Dilma. Nesse processo, buscamos avaliar potenciais reforços ou desafios a estereótipos de gênero nessas construçōes discursivas. Isso porque entendemos, com Dryzek (2000, p. 18), que discursos são modos partilhados de dar sentido ao mundo, encarnados em linguagem e alicerçados em premissas, julgamentos e anseios.

Antes de proceder a essa apresentação, contudo, cabe mencionar, em linhas muito gerais, alguns aspectos fundamentais da construção discursiva produzida pela campanha da candidata Dilma, a qual foi coordenada pelo publicitário João Santana. Salientamos, antes de tudo, a repetição sistemática de alguns segmentos do programa. Há não apenas diversas repetições de programas inteiros, mas também muitas remontagens de blocos que recebem novas suturas para a composição de um todo coerente.

No primeiro turno, os programas apresentavam a candidata Dilma ao público, assumindo duas direçōes: ora enfocavam sua trajetória política, ora revelavam detalhes de sua vida pessoal. Estabelecia-se um equilíbrio ao apresentar uma candidata determinada, forte e valente, ao mesmo tempo em que se buscava humanizá-la, ressaltando sua vida sentimental. A primeira dimensão emerge na reite- ração da experiência adquirida por Dilma nos anos em que foi secretária de Finanças de Porto Alegre, ministra de Minas e Energia do Rio Grande do Sul, presidente do Conselho da Petrobras e ministra-chefe da Casa Civil, "o cargo mais importante depois do presidente". A segunda dimensão aparece por meio do foco nos detalhes de sua vida, como a militância contra a ditadura, a prisão, o casamento e o nascimento de sua filha.

O elo entre a figura política/pública e a privada atravessa os programas que destacavam Dilma como a candidata que continuaria o legado do governo Lula. Vários programas reforçaram o papel fundamental que Dilma teve em programas como PAC, Minha Casa, Minha Vida e Luz para Todos, bem como em diversas obras grandiosas, particularmente no Nordeste. Havia também um esforço para retratar as políticas e os programas sociais estabelecidos em diversas regiōes do país, no que tange as áreas de saúde, educação e segurança.

Em meados do primeiro turno, no programa da tarde do dia 9 de setembro, assistimos a um discurso do Lula aludindo para o sexismo presente na campanha do adversário que buscou "atingir" Dilma, "uma mulher de qualidade" com "mentiras e calúnias". Lula enfatiza que isso é "um crime contra o Brasil e, em especial, as mulheres brasileiras". Esse é o único momento nos programas do primeiro turno em que percebemos como a marcação de gênero é associada a alguma desvantagem na campanha política devido a estereótipos negativos e "mentiras" que Lula define como um "preconceito contra a mulher".

No segundo turno, nota-se uma oscilação entre programas temáticos e programas mais gerais sobre diversos assuntos de campanha. Entre os programas temáticos, destacam-se aqueles destinados à economia, aos esportes (copa/olimpíadas), à agricultura, ao meio ambiente e energia. Alguns programas apresentam sínteses do desempenho de Dilma em debates televisivos. O programa de 26 de outubro, em particular, enfoca a agenda de propostas da candidata voltadas especificamente às mulheres.

A temática mais presente ao longo do segundo turno, contudo, é a questão das privatizaçōes. Dilma é reiteradamente apresentada como a "presidente que não vai privatizar o pré-sal". O candidato 
José Serra é acusado a todo instante de comandar diversas privatizaçóes durante o governo FHC e de querer vender "as riquezas nacionais" para "grandes empresas internacionais". Os ataques a Serra também incluem acusações de insinceridade, seja pela assinatura de um documento em que ele se comprometia a cumprir integralmente o mandado de prefeito de São Paulo caso fosse eleito, seja por ocasião do episódio rolo de fitalbolinha de papel em um confronto com manifestantes do PT.

Um último aspecto a ser ressaltado, ao qual voltaremos na análise mais fina dos enquadramentos, diz respeito à apresentação da candidata Dilma como a garantia da continuidade dos programas sociais do governo Lula. Em diversos programas, ressalta-se que 28 milhões de brasileiros teriam saído da condição de miséria e que 36 milhôes teriam entrado para a classe média. Isso faz com que o próprio presidente Lula interpele o telespectador, quase que diariamente, a tomar uma decisão: "Está na hora de você escolher o Brasil que você quer. [...] O Brasil que dava errado ou o que agora está dando certo". Comparaçóes entre os oito anos de governo do PT e os oito do PSDB foram muito recorrentes nessa construção argumentativa.

Delineados esses pontos gerais sobre a tônica do discurso apresentado pelos programas de Dilma em ambos os turnos, passamos agora à análise da temática enfocada no presente artigo.

\section{A construção do feminino no HGPE de Dilma}

Como apontado anteriormente, os quatro enquadramentos que norteiam a análise são atravessados por sobreposições e tensões. Nenhum deles apresentou-se de forma pura, o que coincide com a própria complexidade das matrizes do pensamento feminista que as fundamenta. Cabe ressaltar, então, que encontramos uma variação modificada de cada um, uma negociação ambivalente em certas instâncias entre os próprios discursos (Squires, 1999, p.132), ou um desdobramento entre um e outro. Assim, os discursos servem como um mapa capaz de detectar se noçôes específicas sobre gênero foram ou não usadas e representadas no HGPE de Dilma.

\section{Discurso da igualdade}

A ideia da igualdade sempre foi extremamente importante para as lutas feministas. Desde as reivindicações da segunda metade do século XIX em torno do sufrágio universal, muitos indivíduos e coletivos buscaram expandir a igualdade propelida pelas revoluções burguesas de modo a que as mulheres fossem incorporadas ao status de cidadania. Como bem destaca Nancy Fraser (1996), em sua análise sobre o percurso histórico do movimento feminista nos Estados Unidos, a base da estruturação desse movimento foi tecida em torno da ideia de igualdade. A demanda fundamental era de que as mulheres fossem tratadas da mesma maneira que os homens, visto serem tão capazes quanto eles e, por isso, merecedoras do princípio de dignidade universalizado na modernidade (Taylor, 1997; Honneth, 2003).

O projeto ou discurso da igualdade busca transcender as noções e as práticas acerca da diferença de gênero que têm discriminado as mulheres, impedindo sua participação na esfera pública (Squires, 1999, p. 117). O objetivo do discurso da igualdade é mostrar como a marcação de diferença de gênero serviu para reforçar o próprio sistema patriarcal, ao mesmo tempo em que legitimou as crenças segundo as quais mulheres são inferiores, menos racionais e mais fracas do que os homens. Nancy Fraser $(1997,2003)$ ressalta que os esforços do discurso da igualdade buscam trazer à tona o fato de a subordinação das mulheres ter sido estabelecida por uma má distribuição de recursos e pela marginalização, o que só pode ser remediado com participação igualitária e redistribuição. Em última instância, o foco da igualdade busca eliminar a diferença e estabelecer padrões de interação em que homens e mulheres, bem como outras coletividades, podem participar da vida social como pares (Fraser, 2003)

Nesse sentido, o "enquadramento da igualdade" questiona as profundas assimetrias entre homens e mulheres, apregoando a urgência de um mundo mais equânime, em que os sujeitos estejam em pé de igualdade. ${ }^{12}$ Tematizando a opressão sistemática a que mulheres estão submetidas e a ausência destas em diversas esferas sociais, tal discurso 
ressalta que as mulheres devem se igualar aos homens, celebrando conquistas obtidas nessa direção e denunciando as assimetrias existentes.

$\mathrm{O}$ quadro da igualdade manifesta-se ao longo do HGPE de Dilma de três formas. A primeira, de natureza tácita, emerge em algumas falas da candidata marcadas pela não adoção de substantivos masculinos de uma maneira genérica. Os excertos abaixo, em que Dilma fala diretamente para seus espectadores, são ilustrativos desse cuidado: ${ }^{13}$

Dilma: Eu tenho a chance de consolidar um processo de crescimento do Brasil, de inclusão dos brasileiros, de melhoria da vida das brasileiras. Eu tenho essa oportunidade [HGPE, 19/10 noite, repetido em 20/10 tarde e 28/10 noite].

Dilma: Eu só tenho a agradecer a todas as brasileiras e a todos os brasileiros que estão ao meu lado e ao lado do presidente Lula nessa caminhada pela construção de um Brasil cada vez melhor [HGPE, 25/10 tarde].

Nota-se aqui um esforço em endereçar homens e mulheres de modo a promover a igualdade na própria prática discursiva. A efetividade da mobilização desse discurso também aparece na forte presença de mulheres ao longo dos programas do HGPE, seja como narradoras, seja como mulheres comuns que falam de suas experiências, seja na voz da própria Dilma. Esses exemplos são sutis, mas indicam uma luta por igualdade, que impede que o masculino se torne sinônimo de ser humano (Miguel, 2000). ${ }^{14}$

A segunda forma de manifestação do quadro da igualdade aparece nos trechos que ressaltam a inserção das mulheres no mercado de trabalho. Tal conquista pode ser atribuída, em grande medida, à segunda e terceira ondas do movimento feminista, contra as discriminaçōes no mercado de trabalho e pela presença das mulheres na esfera pública. Alguns segmentos trazem imagens da atuação de mulheres em áreas tradicionalmente restritas a homens. Um exemplo interessante é uma fala do narrador, veiculada nos programas do dia 31/08 e 2/09: "Hoje, mulheres e homens trabalham lado a lado ajudando a construir um novo Brasil". No segundo turno, para além da construção de um novo Brasil, esse trabalho "lado a lado" é associado ao fortalecimento da "família brasileira" (9/10). As imagens exibem trabalhadoras e trabalhadores com uniformes em seus locais de trabalho e famílias reunidas em casa. No dia 16/09, o narrador afirma que uma série de "obras empregam mais de 20 mil trabalhadores. Boa parte, mulheres. No governo Lula e Dilma, o espaço delas no mercado cresceu como nunca".

Em outros segmentos, os programas focam as experiências de mulheres trabalhadoras que exercem uma profissão tipicamente considerada masculina, como a de carpinteira e soldadeira. Há claramente uma demarcação de igualdade na fala das mulheres que enfatizam como certos preconceitos foram vencidos, provando que as mulheres são "capazes daquilo que alguns homens acham que não somos" (26/10 tarde). A história de Aldiane Lima, carpinteira, é usada para ilustrar a ruptura com a cisão que relegava as mulheres à esfera privada:

\section{Aldiane Lima: Antigamente havia barreiras, a mulher era só em casa. Só lavando roupa. E hoje, não. Hoje já é diferente. Eu me sinto me- lhor, mais valorizada [HGPE, 16/9 noite, repe- tido em 18/9 tarde].}

Uma operária explica que as mulheres têm ocupado novos lugares no mercado de trabalho, contestando exclusōes antigas:

Operária anônima: É uma coisa assim, que ninguém via uma mulher soldando, ninguém via uma mulher trabalhando com máquina. Ninguém via uma mulher fazendo um trabalho que os homens, só os homens podiam fazer [HGPE, 26/10 tarde e 27/10 tarde].

É dentro desse contexto que a própria Dilma procura contestar a ideia de que cargos ligados à chamada hard politics não possam ser ocupados por mulheres. Interessante que sua estratégia busque alinhar traços historicamente caracterizados como femininos ("frágil," "meiga") a traços tidos como 
masculinos e considerados importantes para o cargo de presidente ("assertivo"). A própria Dilma se utiliza de oposições binárias para ressaltar a inserção da mulher na política:

Dilma: Muitas vezes as mulheres foram, pelo menos, secretária de Educação. Agora, tinha certas áreas que era como se estivesse escrito na porta 'vedada a entrada de mulheres'. Porque também tem o estereótipo, né? Frágil e Meiga. A gente é frágil e meiga, mas não é só frágil e meiga. Somos capazes de decidir. Temos posição; somos assertivas [HGPE, 10/10 tarde e noite, repetido nos dias 12/10 tarde e 28/10 noite].

A terceira, e mais explícita, manifestação do discurso da igualdade ocorre em segmentos cuja mensagem principal evidencia a luta por, e a conquista de, direitos de uma forma mais ampla. É, mais uma vez, na fala da candidata, que essa questão emerge de modo muito claro:

Dilma: As mulheres lutaram muito para conquistar seus direitos, para conquistar seu lugar no mercado de trabalho, na arte, no esporte, na política. Minha candidatura simboliza essas novas conquistas. Caso seja eleita vou honrar o meu compromisso com todas as mulheres brasileiras [HGPE, 29/10 tarde e noite].

É importante salientar que a questão de gênero ganha importância à medida que a campanha se aproxima do final. Grande parte dos segmentos que abordam a temática de maneira direta ocorrem nas proximidades da votação do segundo turno, como o excerto acima, exibido no último programa do HGPE. Dois outros trechos do mesmo programa reforçam o compromisso com um projeto político que daria continuidade às conquistas relacionadas com a igualdade de gênero:

Narrador: O Brasil despertou para suas mulheres e sonha com um país sem preconceito, sem discriminação, sem violência doméstica, onde homens e mulheres tenham direitos iguais [HGPE, 29/10].
Varias mulheres: O Brasil que eu quero, é um país com igualdade de condiçôes entre homens e mulheres. Com respeito e tolerância. Onde ninguém tenha medo do presente e o futuro seja sempre melhor. Esse é o nosso Brasil. Esse é o Brasil de Dilma [HGPE, 29/10].

Os segmentos buscam fortalecer a imagem de comprometimento com um projeto nacional que fomenta a emancipação das mulheres brasileiras. No primeiro segmento, ouve-se o hino nacional; no segundo, uma mulher beija a bandeira do Brasil; em ambos, procura-se evidenciar uma ideia de cidadania universal, que não restringe aos homens a participação na vida pública.

Os exemplos explorados nesta seção buscam situar homens e mulheres em um mesmo campo e com as mesmas capacidades. Eles projetam uma igualdade complexa, que questiona assimetrias perpassadas no imaginário social e manifestadas em práticas concretas no mercado do trabalho e em vivências cotidianas.

\section{A marcação da diferença}

O discurso da diferença tem sido colocado frequentemente em oposição ao da igualdade. Está além do alcance deste artigo abordar esse extenso debate ${ }^{15}$ dentro do feminismo. Delinearemos, em contrapartida, o que chamamos de quadro da marcação da diferença, buscando distingui-lo do enquadramento da igualdade. Da perspectiva feminista, teóricos(as) da diferença buscam "trazer ao centro aquilo que é atualmente marginalizado, valorizar aquilo que é desvalorizado, privilegiar aquilo que é atualmente subordinado (Squires, 1999 , p. 118). Trata-se, como bem apontam Butler (2000) e Fraser (1997), de uma abordagem que procura ressignificar identidades marcadas por estereótipos negativos, de modo a positivá-las. No movimento feminista norte-americano do final dos anos de 1970, por exemplo, a tônica era valorizar as especificidades das mulheres em vez de buscar uma suposta igualdade em relação aos homens (Fraser, 1996).

Nesse sentido, o discurso da diferença privilegia experiências, vozes e perspectivas das mulheres 
(Squires, 1999; Dietz, 2003). Ele enfatiza traços supostamente específicos da identidade feminina, rompendo com uma lógica que se articula a partir dos princípios de racionalidade e neutralidade. Teóricos(as) da diferença veem a neutralidade como um ideal androcêntrico, que sustenta práticas e estruturas patriarcais. Assim, a marcação da diferença confere um grau de valoração no feminino em contraponto ao masculino, reconhecendo que a forma de escapar da opressão é compreender essa identidade particular.

No HGPE de Dilma, encontramos diversas tentativas de demarcar a diferença de gênero. Em vários segmentos, essa questão é destacada, sobretudo em virtude do fato de que Dilma se viabilizava como a primeira mulher com chances efetivas de vencer as eleiçôes presidenciais. Um dos principais jingles da campanha, veiculado quase que diariamente, destaca a centralidade da demarcação de gênero na estratégia de campanha. A música acompanha imagens de paisagens de diversas regiôes do país, representando idosas, adultas, jovens, crianças, brancas, negras:

Jingle: E o país vai seguir mudando; é o que a gente quer: seguro e com fé nas mãos dessa mulher. Meu Brasil, tá querendo Dilma. Meu Brasil, tá querendo continuar. Agora é Dilma, é a vez da mulher.

A diferença de gênero traz mudança e inovação ao discurso de continuidade adotado pela campanha do PT. O discurso, então, pauta-se pelo ineditismo. Isso aparece de forma eloquente na apresentação da biografia de Dilma, também repetida em diversos programas com pequenas variaçōes de texto:

Narrador (masculino) ${ }^{16}$ : Dilma foi muitas vezes pioneira. Ela foi a primeira mulher a ser secretária de finanças de Porto Alegre e secretária de Minas e Energia do Rio Grande do Sul. Foi a primeira mulher a ser ministra de Minas e Energia e a presidir o conselho de administração da Petrobras. E graças a sua competência, se tornou a primeira mulher a ser ministra-chefe da Casa Civil e coordenar todo o ministério.
Quem tem uma biografia dessas tem tudo para ser a primeira presidente do Brasil.

Esses segmentos acompanham fotos em preto e branco de Dilma exercendo cada cargo e, muitas vezes, um número "1" é sobreposto às imagens. Tais fotografias servem de testemunho histórico da ocupação de tais cargos, construindo uma narrativa de passado que conduz a um futuro proposto: "tem tudo para ser a primeira presidente do Brasil".

Essa possibilidade inédita é destacada em diversos momentos pelo então presidente Lula, por eleitores que tiveram depoimentos colhidos no esquema "Povo Fala" e pelo narrador, como ilustram os trechos abaixo:

Lula: Já tivemos a coragem de votar em um metalúrgico e agora em uma mulher [HGPE, 24/8 tarde, repetido em 26/8 noite e 28/8 noite].

Lula: Eu realmente fico muito feliz de saber que eu posso entregar a faixa presidencial para uma companheira do meu partido e uma companheira mulher é uma coisa gratificante [HGPE, 17/8 tarde, repetido em 19/8 noite].

Eleitor: Hoje nós temos a mulher dentro da política, falta uma mulher presidente. Porque a mulher, mãe, ela é dona de casa. Ela é muito dedicada. E o Lula jamais iria colocar... na mão de alguém que não conhecia [HGPE, 9/9 noite].

Narrador: Um futuro que começa agora, a partir de uma base sólida, criada pelo melhor presidente da nossa história e pela primeira mulher a ocupar os mais altos cargos do governo [HGPE, 2/9 noite, repetido em 4/9 noite].

Dilma também busca demarcar o fato de ser mulher, talvez em uma tentativa de se aproximar do eleitorado feminino. Em um segmento, veiculado no dia $17 / 8$ à tarde (e repetido na noite do dia 19/8), ela afirma: "É em nome de todas as mulheres do Brasil em especial da minha mãe e da minha filha que recebo essa homenagem e essa indicação para concorrer à presidência da República”. No segundo turno, Dilma continua expressando seu 
orgulho por ser uma mulher candidata na disputa para presidência e busca transferir esse sentimento para o eleitorado ao mostrar a boa votação que ela e Marina Silva tiveram:

Dilma: Agradeço de coração aos mais de 47 milhôes de eleitoras e eleitores que me deram o seu voto. E chamo sua atenção para um fato bem curioso: se a gente somar meus votos com os da candidata Marina Silva, a gente vê que cerca de $67 \%$ dos brasileiros querem uma mulher na presidência. Isso é um motivo especial de orgulho para todas nós mulheres brasileiras. E também de muita responsabilidade, porque tão importante quanto ser mulher é defender o melhor projeto para o Brasil [HGPE, 8/10 tarde].

Para além do destaque permanente do atributo identitário "mulher" nas falas de diversos atores mobilizados pelo HGPE de Dilma, é possível destacar uma segunda maneira de marcação da diferença de gênero nos programas. Referimo-nos, aqui, à valorização da diferença expressa na ênfase de políticas desenvolvidas para mulheres, desde o governo Lula. Políticas essas que buscariam romper barreiras econômicas, políticas e culturais que historicamente erigiram um quadro de opressão estrutural, para usar os termos de Iris Young (2000).

Os trechos que demarcam políticas para as mulheres estabelecem um elo de continuidade com o governo Lula. Isso não apenas porque Dilma é apresentada como a principal ministra do governo petista, mas também porque o fato de ser mulher confere mais credibilidade à promessa de manutenção e aprofundamento dessas políticas. Convém mencionar, ainda, que essas políticas voltadas a mulheres são frequentemente apresentadas como açôes destinadas ao fortalecimento da família brasileira, o que se torna importante, para Dilma, sobretudo no segundo turno, quando rumores de que ela seria ateia e favorável à legalização do aborto se espalham. ${ }^{17}$ É nesse contexto que Dilma fortalece o foco na soft politics, vinculando açōes na área de saúde, moradia, educação e segurança às mulheres.

Narrador: É para apoiar ainda mais mulher brasileira que Dilma vai ampliar linhas de crédito que estimulam a mulher a organizar cooperativas e microempresas; construir 6 mil creches e pré-escolas, garantindo mais educação para as crianças e mais oportunidades de trabalho para as mães; criar a Rede Cegonha; atendimento à mãe da gravidez até o primeiro ano do bebê; garantir cursos de capacitação profissional para as mulheres que querem entrar no mercado de trabalho; ampliar os exames de mamografia em todo o país; e combater qualquer discriminação contra a mulher [HGPE 26/10 tarde, repetido em 27/10 tarde].

Narrador: Para fortalecer a familia brasileira, Dilma vai construir mais 2 milhôes de moradias. E, ao mesmo tempo, melhorar o sistema de saúde e construir 500 UPAS, as unidades de pronto atendimento que funcionam 24 horas. [...] Segurança é outra prioridade. Dilma vai investir fortemente em policiamento comunitário e articular programas que protegem os jovens das drogas. [...] É assim, com essas ações integradas que Dilma vai apoiar a família brasileira [HGPE, 08/10 tarde, repetido em $12 / 10$ noite; $13 / 10$ tarde e noite; $14 / 10$ tarde].

O primeiro segmento é acompanhado por imagens em que Dilma conversa com mulheres em ambientes públicos e privados, evidenciando que ela está atenta à fala das mulheres. Cenas de mulheres e crianças sorridentes, de mulheres em seus locais de trabalho e de mães amamentando também são recorrentes. Um tom mais sério e indignado cobre os rostos quando se menciona a questão da discriminação, mas o segmento termina com uma sequência rápida de sorrisos femininos e com uma cena em que Dilma aparece em meio a várias mulheres com uma camisa na qual se lê "Mulheres da Paz".

O foco em políticas voltadas a mulheres é sistematizado no programa vespertino de $26 / 10$, dedicado centralmente a essa questão. Nele, uma apresentadora explica a atenção de Dilma para com as mulheres durante o governo Lula:

Apresentadora: O governo de Lula e Dilma criou a Secretaria de Políticas para as mulhe- 
res e o serviço ligue 180 para apoiar e orientar a mulher vítima de violência. Sancionou a lei Maria da Penha, que estabeleceu penas mais duras contra os agressores de mulheres. Garantiu às trabalhadoras domésticas direito a férias e estabilidade no emprego durante a gravidez. Estimulou as empresas a estender a licença maternidade para seis meses. Criou o Pronaf mulher, uma linha de crédito especial para a mulher que trabalha no campo. Além disso, a escritura de terras em assentamentos rurais que só saía em nome do homem, agora sai em nome do casal. Mudança assim, as mulheres brasileiras nunca tinham visto [HGPE, 26/10 tarde, repetido em 27/10 tarde].

A apresentação de segmentos que identificamos como manifestações do quadro da diferença deixa transparecer algumas conexôes com outros enquadramentos abordados nessa análise. Se, por um lado, trata-se de políticas específicas e que salientam particularidades tidas como femininas, por outro, algumas dessas políticas buscam promover a igualdade de gênero. Ademais, a marcação da diferença já abre caminho para o terceiro quadro a ser abordado: a ética do cuidado. A atenção a mulheres e às suas famílias insinua a existência de um olhar marcado pelo zelo, pelo carinho e pela proteção da família. Nesta seção, concentramo-nos em marcar a diferença de gênero (seja de Dilma, seja de parte de seu eleitorado). No enquadramento da ética do cuidado, apontaremos uma espécie de desdobramento dessa marcação, o qual ocorre quando a diferença deixa de ser destacada por si e adquire conteúdo e substância específicos.

\section{A ética do cuidado}

O discurso da ética do cuidado configura-se como uma espécie de subenquadramento no interior do quadro mais amplo da marcação da diferença, uma vez que toda manifestação daquele envolve esta, ainda que nem toda instância de marcação da diferença se configure como ética do cuidado. Nesse sentido, este quadro também enfatiza a diferença entre homens e mulheres e afirma a positividade de muitas características femi- ninas para a esfera da política (Chodorow, 1989, 1999; Gilligan, 1982; Elshtain, 1981). Nessa abordagem, as mulheres seriam mais carinhosas, mais emotivas, menos bélicas e competitivas. Mulheres cuidam. As diferenças entre homens e mulheres seriam baseadas nas distintas prioridades, valores e interesses das mulheres. Por isso, elas atuariam na política de forma diferenciada. Partindo dessas características, a perspectiva de uma ética de cuidado pressupóe uma voz moral de natureza distinta, a qual se associa mais fortemente à maternidade (Gilligan, 1982).

O quadro da ética do cuidado produz um elo entre a esfera privada (espaço tradicionalmente vinculado à feminidade) e o espaço da política. A entrada da mulher na política é vista como uma extensão da atuação da mulher na esfera doméstica. De acordo com essa visão, a presença feminina no poder garantiria a superação da racionalidade instrumental que coloca o êxito econômico à frente do cuidado com o outro. As mulheres seriam capazes de oferecer uma "visão não hierárquica da conexão humana" (Idem). Esse enquadramento sinaliza, assim, a viabilidade de uma prática política menos competitiva, cínica e corrupta.

$\mathrm{Na}$ análise do HGPE, de Dilma, pode-se perceber, claramente, como o discurso opera, de maneira frequente, com um plano que enfatiza o cuidado e o carinho. Nos programas analisados, há diversos segmentos dedicados a argumentar que diferentemente de outros governantes, o modelo adotado por Dilma pautar-se-ia por uma maneira afetiva de agir, em detrimento de uma lógica fria puramente racional. $\mathrm{O}$ excerto a seguir, reproduzido em diversos programas, deixa isso claro:

Narrador: Alguns governos veem o mundo só pelos olhos da economia. Aí tudo vira número. Outros governos veem o mundo só pelos olhos das obras. Aí, tudo vira pedra, tijolo, prédio. $E$ há um tipo raro de governo que vê o mundo pelos olhos das pessoas. Aí número vira gente, prédio vira gente e gente vira muito mais gente. É este governo de olhar social, onde as pessoas são o centro de tudo que Lula vem fazendo e Dilma vai continuar e ampliar [HGPE, 27/10 noite, repetido em 27/10 tarde]. 
Curiosamente, tal cuidado não seria exclusividade feminina. De um modo geral, Dilma é retratada como a continuadora do legado de Lula, uma espécie de pai do povo que cuida de seu país. Dilma parece ocupar, assim, a figura de mãe do Brasil, algo explicitamente proposto por Lula na metáfora da "Mãe do PAC" - muito mobilizada pelo presidente ao longo da campanha, ainda que não nos programas do HGPE. ${ }^{18}$ Como bem aponta Pires, "o uso estratégico dessa alegoria feminina possibilitou tanto a sustentação do argumento de que o modelo de governo de Dilma Rousseff era o mesmo do presidente da República, Luiz Inácio Lula da Silva, como funcionou como apelo emocional" (2011, p. 140).

A metáfora materna ultrapassa o sentido da criação e da coordenação de um programa governamental e traz à tona o quadro da ética do cuidado. O povo elegeu Lula como seu pai, e agora é a vez de eleger uma mãe, capaz de articular "sensibilidade e objetividade". ${ }^{19}$

Marilane Dantas: A comunidade chama Lula de pai. porque realmente foi um homem que se preparou pra isso. Pra dirigir seu país [...]. O pai do povo é ele. E eu espero que a Dilma Rousseff seja a mãe do povo [HGPE, 26/8 noite, repetido em 28/8 tarde].

Um jingle delineia claramente essa ideia de uma passagem da nação brasileira das mãos do "pai do povo" para a "mãe do povo":

Jingle: As mãos de uma mulher vão nos conduzir [...] o povo ganhou uma mãe, que tem um coração que vai do Oiapoque ao Chuí. Deixo em tuas mãos o meu povo [HGPE, 17/8 noite, repetido em 19/8 tarde].

A ideia dos gestores/genitores é reforçada em vários segmentos em que pessoas extremamente pobres se emocionam com a mudança de suas vidas. É o caso de um trabalhador da obra de transposição do Rio São Francisco que pede a Deus que abençoe o presidente Lula e lhe dê forças para continuar trabalhando, "porque o teu povo precisa disso" (HGPE, 16/10 noite). Também é o caso do pedrei- ro que havia chegado a caminhar de uma cidade a outra em busca de serviço sem qualquer êxito (HGPE, 13/10 noite). O contraste entre o Brasil da miséria e a nova realidade promovida pelo governo de gestores/genitores é sintetizado em outro segmento:

Narrador: Durante grande parte de sua história, o Brasil foi um país dividido e injusto. De um lado, fome e miséria. Do outro, riqueza e progresso. Até que duas coisas inéditas aconteceram. O pais elegeu Lula, seu primeiro operário presidente e uma mulher, Dilma, passou a coordenar todas as açōes do governo. Com essa uniāo começou a surgir um novo Brasil. Mais justo e próspero. 28 milhões de pessoas saíram da miséria e a comida chegou à mesa de outros tantos milhôes graças a programas como o Bolsa Família [...]. Com Dilma fica a garantia: o Brasil vai avançar nesse caminho que está fazendo nosso povo mais feliz [HGPE, 16/10 noite, repetido em 17/10 tarde].

As imagens do segmento contrapõem fotos típicas de miséria (casebres com pessoas pobres a encarar, desconfiadas, a câmera) de grandes cidades. Depois de imagens da posse de Lula e da atuação de Dilma no ministério, notam-se cenas de crianças felizes a estudar e a se alimentar, de uma camponesa e de pescadores sorridentes, de pessoas se abraçando. Cuidadosa, Dilma cumprimenta pessoas em lugares aparentemente pobres e em um hospital. No colchete da citação acima, insere-se a fala de uma senhora que chora ao abordar a mudança da vida de incerteza e privação para a vida mais feliz e segura experienciada agora.

Nota-se, assim, que o olhar humanizado e social da "mãe do povo" teria gerado projetos que buscaram beneficiar famílias e regiōes menos desenvolvidas em todo Brasil. Projetos esses que requereriam, argumenta a própria candidata, uma percepção afetiva dos problemas sociais:

Dilma: Para você achar que tem que mudar o seu país, você tem que ter uma relação afetiva com seu povo também, E você sim, ou seja, tem 
que te incomodar afetivamente não é só racionalmente, afetivamente, a pobreza. Afetivamente... Criança sem recurso. E a mim sempre afetivamente me tocou muito uma coisa, que eu vi muito isso... a humildade do povo [HGPE, 17/8 tarde, repetido em 19/08 noite].

Frequentemente estereotipada como mulher fria (ou até truculenta), Dilma busca se inserir em um quadro de sentido que opera com a lógica do afeto, da sensibilidade e do carinho. Com isso, busca desvincular-se do estereótipo masculino, que, supostamente, prioriza a racionalidade em detrimento a emoção, o que não implica abrir mão da objetividade. Dilma representaria um modo de governar respeitoso, que busca erradicar a miséria, cuidar das famílias e garantir a dignidade dos lares.

Narrador: A visão da mulher é capaz de mudar muita coisa. Da mulher, mãe. Da mulher, avó. Da mulher que respeita a vida. Da mulher que percorre o mundo divulgando o nosso país. $\mathrm{Da}$ mulher que, coordenando todos os ministérios do governo lula, pensou em primeiro lugar na família brasileira. E assim, criou o Luz para Todos, que iluminou milhóes de casas Brasil afora. Fortaleceu o Bolsa Família, que levou comida a tanta gente. Coordenou o programa Minha Casa, Minha Vida, que está realizando o sonho da casa própria de milhares de famílias. E levou em frente o Programa de Aceleração do Crescimento, o PAC, que gerou milhares de empregos e devolveu a dignidade a tantos Lares. Essa é Dilma, que com a força e a fé da mulher vai fazer o Brasil seguir mudando (HGPE, 12/10 noite, repetido em $13 / 10$ tarde). ${ }^{20}$

$\mathrm{O}$ excerto reproduzido acima é eloquente. Demarca a questão de gênero, liga-a à maternidade e vincula uma série de políticas ao cuidado com a família e com o lar. No plano imagético, notam-se fotos de Dilma segurando bebês de colo, abraçando outras mulheres e estendendo a mão a crianças. Famílias sorridentes posam em frente a suas casas. Mulheres exibem o cartão do Bolsa Fa- mília, e crianças aparecem se alimentando. Veiculado no início do segundo turno, o segmento faz parte da tentativa dos estrategistas da campanha de rebater rumores de que Dilma seria a favor da legalização do aborto, ateia e, quiçá, lésbica. Por isso a ênfase na "força e na fé da mulher". Convém citar que, no mesmo programa, Dilma ressalta tratar-se do dia da criança e de Nossa Senhora Aparecida, renovando seu compromisso com as crianças e com os valores da solidariedade, da fraternidade e da fé (HGPE, 12/10 noite). ${ }^{21}$ Ao recorrer à Nossa Senhora, ícone clássico da maternidade, Dilma ressalta a importância de lutar contra as desigualdades e injustiças.

Algumas das propostas de campanha da candidata evidenciariam todo o cuidado e o espírito maternal da candidata, o que se faz marcante pelo destaque dados às crianças:

Narrador: O Brasil de Dilma vai oferecer um futuro de paz e alegria para suas crianças. Porque ela sabe que para uma nação ser digna desse nome, tem de cuidar de suas crianças. Desde o momento em que cada coraçãozinho comę̧a a bater dentro da barriga da mãe. Por isso, Dilma vai criar a Rede cegonha, um programa de cuidado total com a mãe e o bebê. Ela também vai ajudar as crianças a abrir os olhos para a vida e a se conhecer. Fazer com que elas tenham onde brincar, dizer umas às outras as suas primeiras palavras. Por isso, Dilma vai espalhar 6 mil creches e pré-escolas pelo país. E o Brasil será um país de todas as crianças (HGPE, 29/10 tarde, repetido à noite).

Como se nota, o quadro da ética do cuidado confere substância a uma suposta essência femini$\mathrm{na} /$ maternal que assume uma responsabilidade com o cuidado e a proteção. Os trechos a seguir fornecem mais algumas ilustraçōes desse aspecto, sendo interessante salientar que, neles, é Dilma quem interpela, diretamente o eleitor:

Dilma: Quero fazer com cuidado de mãe o que ainda precisa ser feito, este é meu sonho. Governar com amor, coragem [HGPE, 17/8 noite, repetido em 19/8 tarde]. 
Dilma $^{22}$ : Talvez só as mulheres, as mães tenham essa força, porque mãe vai até o fim pra salvar seu filho, né? [HGPE, 4/9 noite, repetido em 7/9 tarde].

Dilma: Acho que a gente quando nasce um filho, sabe qual a sensação? De que você é uma pessoa privilegiada. Essa doação sem pedir nada em troca é única, é única na vida [HGPE, $10 / 10$ tarde, repetido em $10 / 10$ noite, $12 / 10$ tarde, 28/10 noite].

Dilma: Mulher tem essa, esse lado do cuidado e acho que nós também temos uma característica: a gente olha o processo inteiro - do início ao fim, quase analiticamente. Acho que os homens são mais sintéticos. Então, mulher cuida, cuida mesmo [HGPE, 17/10 noite, repetido em 19/10 tarde].

Dilma: $\mathrm{O}$ que é preciso é fazer as duas coisas: cuidar do meio ambiente e cuidar das pessoas. Pra mim, cuidar das pessoas é ajudá-las a subir na vida, a realizar seus sonhos. Foi isso que o governo do presidente Lula fez. É isso que o meu governo vai continuar fazendo: olhar para as pessoas [HGPE, 22/10 noite, repetido em $23 / 10$ tarde].

O discurso verbal da candidata delineia uma espécie de presidente/mãe, que sabe se doar sem pedir nada em troca e que governa com carinho para cuidar de pessoas e para permitir que realizem seus sonhos. A mulher não seria sintética, instrumental, focada apenas nos fins. Ela "olharia o processo todo", zelando pelo bem estar daqueles afetados por certo curso de ação. Corroborando a fala de Dilma, outros atores são convocados a ressaltar o traço do cuidado como intrínseco à forma de atuação da mulher:

Maria Regina Ponce (eleitora/operária): Eu acredito que a sensibilidade da mulher é que vai mudar realmente este pais [HGPE, 24/8 tarde].

Leonardo Boff: Ela não vem gerenciar um povo. Ela vem cuidar do povo [HGPE, 21/10 tarde, repetido em $24 / 10$ noite e 25/10 tarde].
Várias mulheres: O Brasil que eu quero é um país onde os filhos da gente tenham tudo o que é preciso para nascer e crescer. Tenham creche e pré-escola enquanto a gente trabalha. Toda mãe quer isso e toda criança tem esse direito. Por isso, somos Dilma, Dilma, Dilma [HGPE, 29/10 tarde, repetido à noite].

Esses trechos são claras ilustraçóes de como a própria linguagem da ética do cuidado produz e reforça imagens que associam mulheres com uma voz ou perspectiva diferenciada. Essa voz marcada por uma atenção ao cuidado cria um forte elo entre a maneira como mulheres percebem relacionamentos e responsabilidades (Gilligan, 1982, p. 186). Ao se utilizar desse enquadramento, tanto na voz da Dilma quanto na de outros, o HGPE ganha força e legitimidade, associando a mulher a uma imagem aceitável sobre sua atuação na esfera política. Esse discurso trabalha com um imaginário que historicamente tem valorizado o papel da mulher na esfera privada.

Para concluir, mencionamos mais um trecho de um jingle que amarra os sentidos configuradores do quadro da ética do cuidado e evidenciam a reprodução de binarismos típicos desse enquadramento. Nele, reproduzem-se discursos enraizados que retratam a mulher como o pilar moral da sociedade. Uma vez mais, notam-se diversas mulheres, jovens e crianças no plano imagético sorridente Dilma fazendo o "v" da vitória com as mãos. É interessante destacar, aqui, a presença da bandeira e do hino nacionais, ambos produtos da força da tradição positivista na fundação da República. Também se ressalta a tentativa de apresentar as mulheres como fortes e amorosas, a favor da ordem, do progresso e do cuidado:

Jingle: Mulheres são fortalezas divinas, são belas bailarinas, são pretas no branco guerreiras de fé, Mulher, Mulheres são pulso firme mas com a voz e o amor de mãe, são predestinadas a vencer. Assim é mulher. Contra a insegurança, Mulheres a favor do Brasil. A favor da ordem, A favor do progresso. Queremos Mulher [HGPE, 31/8 noite, repetido em 2/9 tarde, $11 / 9$ noite, $14 / 9$ tarde]. 
Cabe salientar, ainda, que, em geral, os jingles operam com diversos estereótipos de gênero tanto na reprodução de imagens quanto na sua linguagem. Um ponto em comum entre os jingles é representar a mulher como doce, sensível, protetora e mãe. Outro jingle ainda afirma que "o feijão tá quente, a mulher tá contente", ressaltando a conexão da mulher com a esfera doméstica.

Observa-se, em suma, que o enquadramento aqui apresentado busca positivar a diferença de gênero, apresentando as mulheres como inerentemente portadoras de atributos que seriam benéficos à política. O Brasil precisaria de uma mãe capaz olhar com carinho, segurança e afeto para seu povo. Contra a lógica fria e vazia do "economês", precisaríamos de alguém que cuidasse de gente. E ninguém melhor do que uma mulher para fazê-lo. Assim, a ética do cuidado usa, estrategicamente, os estereótipos historicamente construídos em torno do feminino, sob pena de reproduzir binarismos e cristalizar a clivagem de gênero que estrutura muitas formas de opressão contemporâneas. Contra tal cristalização, algumas feministas advogam uma perspectiva desconstrucionista, à qual passamos agora.

\section{Desconstrucionismo}

O discurso desconstrucionista questiona a utilização do corte de gênero como forma de classificação social. Tal perspectiva reforça a necessidade de não somente desestabilizar, mas também desmantelar polaridades que sustentaram formas de opressão (Butler, 2000). Apregoando uma transformação profunda das relaçôes sociais, o desconstrucionismo advoga que tanto a busca pela igualdade, como a marcação da diferença conduzem ao reforço de um binarismo opressivo, que alimenta assimetrias e práticas hierarquizantes. Tal discurso rejeita tanto o sexo como categoria biológica quanto o gênero como construção social.

A perspectiva desconstrucionista ganhou momento com a virada linguística, o fortalecimento dos estudos culturais e do pós-estruturalismo. Ressaltando a dimensão discursiva e contingente das identidades, feministas desconstrucionistas propõem uma luta mais estrutural que não reforce binarismos de gênero. Mesmo porque há tantas diferenças no interior de supostos grupos identitários como entre um grupo e outro. $\mathrm{O}$ discurso da igualdade e o discurso da diferença tenderiam, nessa visão, a construir uma imagem unificada da mulher, equivalendo-a ao homem ou contrapondo-a a ele. Assim, negligenciariam os vários cortes que atravessam as identidades femininas, incluindo as de raça, classe, religião e orientação sexual, para citar alguns deles. Ademais, frequentemente, o discurso da igualdade e o da diferença restringiriam as possibilidades de gênero a homens e mulheres, desconsiderando a ampla gama de possibilidades vivenciadas por sujeitos em suas experiências ordinárias.

Nos programas do HGPE, não encontramos manifestaçōes do enquadramento desconstrucionista, o que não é surpreendente, dada sua complexidade e o potencial de geração de estranhamento. Em um contexto eleitoral conservador e balizado por premissas religiosas (Mantovani, 2011), a proposição da desconstrução de gênero poderia desencadear a rejeição de significativas parcelas do eleitorado.

Além disso, segmentos desconstrucionistas só poderiam se manifestar de maneira explícita, na medida em que a opressão de gênero fosse frontalmente tematizada. Não foi essa a estratégia central do programa de Dilma que optou por uma abordagem mais tangencial da questão. Em grande parte da campanha, destacou-se a "feminidade" de Dilma sem que se tratasse a questão da mulher na sociedade. É marcante nesse sentido como apenas no final da campanha, na última semana (programas de 26/10, 27/10 e 29/10) mais precisamente, a questão de gênero foi frontalmente discutida.

\section{Essencialismo estratégico?}

Explorados os segmentos dos programas do HGPE de Dilma e à guisa de conclusão, convém, agora, tecer alguns comentários sobre implicaçōes dos enquadramentos encontrados. Se pensarmos nos quadros utilizados no HGPE de Dilma, percebemos como a maioria dos programas não busca romper com imagens ou discursos vinculadas a uma essência feminina. Nota-se a clara reprodução de estereótipos que engessam e fixam a identidade feminina e que, de algum modo, mantêm-na associada à 
esfera da domesticidade. Como discutido, o enquadramento desconstrucionista não tem qualquer tratamento. $\mathrm{O}$ discurso da igualdade, que poderia ser mobilizado em coerência com dicotomias e sentidos enraizados no imaginário social, também tem uma visibilidade relativamente reduzida. $\mathrm{O}$ foco da campanha de Dilma voltou-se à declaração da diferença da mulher e à associação de tal diferença a uma positividade atrelada às ideias de maternidade, cuidado e afeto (sem perder a capacidade administrativa!).

É importante perceber como o discurso da ética do cuidado acaba por se sustentar em distinções históricas e em uma lógica dicotômica que separam a esfera política da esfera privada. Segundo Pateman (1988, p. 3), a divisão entre público e privado está ligada à origem do contrato sexual, em que a importância política é restrita à esfera pública em detrimento da esfera privada. É essa divisão que cristaliza a condição de cidadania inferior para as mulheres, não somente por confiná-las à esfera privada, mas também por considerá-las politicamente irrelevantes. Nesse quadro, "a maternidade é vista como a antítese da cidadania" (Pateman, 1990, p. 60), bem como uma barreira a inserção da mulher na vida política e ao exercício pleno da sua cidadania.

Os discursos da diferença ou da ética do cuidado podem reproduzir e/ou reduzir as identidades das mulheres a "caricaturas simplistas e exageradas" (Hirschmann, 2003, p. 78). Em outras palavras, a reprodução ou o enfoque em certas caricaturais onipresentes no nosso imaginário serve para (1) continuar naturalizando papéis hierárquicos de gênero e (2) dificultar a inserção das mulheres na política.

Apesar de todos esses riscos, também é possível refletir sobre o uso do discurso da ética do cuidado à luz das discussões feitas por Gayatri Spivak (2002) acerca da noção de essencialismo estratégico. Desconstrucionista prática, feminista e marxista, Spivak é extremamente crítica à ideia de que existem identidades essenciais que os sujeitos deveriam descobrir. Exatamente por isso, ela percebe que a construção política das identidades pode mobilizar o essencialismo estrategicamente no sentido de apresentar um grupo politicamente. Spivak percebe que, na prática, é impossível ao sujeito não realizar alguma forma de fechamento identitário ao se representar. "Uma vez que não é possível não ser essencialista, uma pessoa pode usar esse momento irredutível do essencialismo conscientemente como parte de sua estratégia” (Idem, p. 109). Visto que essas homogeneizações ocorrem, a proposta é ter consciência delas e explorá-las politicamente. Essa dinâmica seria mais frutífera do que o simples repúdio de qualquer essência (Idem, p. 11). ${ }^{23}$

Se a ideia de essência pode ser opressora ao engessar diferenças, também a perda completa da noção de identidade pode agir no sentido de fortalecer injustiças. $\mathrm{O}$ discurso individualista de que cada selfé único, ainda que, teoricamente, irrefutável, pode ser usado para diluir diferenças que afetam coletividades e evitar que problemas específicos sejam coletivamente endereçados. Sem adotar a essencialização pasteurizante, Spivak (2002) advoga um essencialismo estratégico que revela a importância de pensar politicamente as narrativas identitárias a serem publicamente apresentadas.

É preciso deixar claro que Spivak (2002) não advoga a visão do "feminino" focada na ética do cuidado. A rigor, Spivak não prescreve definição alguma da "essência do feminino", mesmo porque ela não acredita em sua existência. Ela recomenda a permanente vigilância dos fechamentos estratégicos, por meio da submissão destes a uma crítica perene. $\mathrm{O}$ que a autora coloca é a necessidade de pensar formas de autorrepresentação - que sempre têm uma dimensão essencializante - para mobilizá-las estrategicamente. É possível pensar, assim, como certas mobilizações de ideias vinculadas a um universo supostamente feminino podem ter implicaçôes politicamente interessantes para certas candidatas, mesmo que se discorde da imagem projetada por elas.

No contexto da agenda eleitoral de 2010, a tática de Dilma buscava combater estereótipos negativos que a caracterizavam como agressiva e/ou masculinizada, e ao mesmo tempo havia necessidade de dialogar com o fortalecimento de opiniōes conservadoras e religiosas na cena pública brasileira. Como bem aponta Jamieson (1995), candidatas frequentemente se deparam com uma espécie de double bind, que cerceia as chances de êxito: por um lado, mulheres são julgadas incompetentes, por outro, aquelas que são vistas como competentes são 
percebidas, frequentemente, como não suficientemente femininas. ${ }^{24}$

Visando a superar esse double bind, Dilma precisou se mostrar apta a liderar, sem ser fria; emotiva e sentimental, sem perder o foco e a racionalidade. Ou seja, viu-se diante do desafio de construir uma imagem pública que opera uma espécie de bricolagem dos estereótipos masculinos e femininos. Ainda de acordo com Jamieson (1995), esse equilíbrio mostra-se pragmaticamente necessário. Susan Carroll (2009) lembra a eficácia de Margareth Thatcher em caminhar sobre essa perigosa lâmina. Por um lado, a preocupação com os vestidos e os tradicionais colares de pérola; por outro, o comportamento agressivo e visto como masculino na política.

Dilma parece repetir esse equilíbrio (aliás, vestindo um colar de pérolas, com frequência, ao longo da campanha). Ao utilizar certas imagens que reproduzem a suposta essência feminina, os programas tiveram êxito em acompanhá-los de imagens que reforçavam a experiência, a força e a objetividade da candidata. Ao demarcar essa diferença, o HGPE de Dilma conseguiu trabalhar no interior, e a partir, de um imaginário fortemente marcado por vestígios do legado patriarcal. Isso facilitou sua interlocução com o eleitorado.

Dilma mostrou-se compassiva e carinhosa. A preocupação com a erradicação das desigualdades sociais e econômicas foi reforçada pela preocupação com a família brasileira, imposta pelo contexto da disputa eleitoral. Em contrapartida, também se apresentou ao eleitorado, quase que diariamente, políticas desenvolvidas por uma candidata com aparente capacidade executiva e firmeza no agir. Dilma foi construída como mãe; mas uma mãe severa e eficiente. Uma mãe que faz o papel visto como de pai, se necessário.

Fica, contudo, a questão de saber quando, e como, candidatas poderão desafiar a imposição de uma androgenia dicotômica imposta pelos quadros interpretativos vigentes e pelo double bind que os acompanha. Certas estratégias eleitorais de que dependem muitas candidatas reforçam o binarismo entre público e privado e o quadro simbólico que alicerça muitos estereótipos de gênero. A linha entre o essencialismo estratégico e a essência estereotipada é tênue e repleta de riscos.

\section{Notas}

1 Caso de Marta Suplicy, Rosinha Garotinho, Roseana Sarney, Heloísa Helena, Ana Júlia, Luiza Erundina e Benedita da Silva.

2 No caso, Hilary Clinton, nas prévias do Partido Democrata, e Sarah Palin, como candidata a vice-presidente do Partido Republicano.

3 Hard politics refere-se a um grupo de questôes políticas que costuma agregar mais prestígio e poder. Soft politics refere-se, então, a questôes políticas das quais as mulheres supostamente se interessam e priorizam mais, incluindo saúde, educação, meio ambiente, direitos humanos, família etc. O interesse em soft politics alinha-se a hipóteses segundo as quais deputadas se veem como uma extensão do papel que elas exercem na esfera privada. A esse respeito, ver Childs (2004); Escobar-Lemmon e Taylor-Robinson (2005); Lovenduski e Norris (2003); Htun e Power (2006); Miguel e Feitosa (2009). Cabe ressaltar que o interesse das mulheres pela chamada soft politics não deve ser entendido como um reforço da ética do cuidado ou da diferença moral entre homens e mulheres. Como Miguel (2000b), Miguel e Feitosa (2009) e Stokes (2005) argumentam, tal interesse se deve mais a um espaço que as mulheres encontraram para atuar, já que os homens monopolizaram as arenas de maior prestígio.

4 A coleta desse corpus contou com a contribuição de Izabel Muniz, Geraldo Frances Vaz e Thaís Victorino, a quem somos muito gratos.

5 Em algumas ocasiōes, esses programas foram encurtados em virtude de direitos de resposta concedidos a outros candidatos.

6 Os spots desempenham um papel fundamental nas campanhas eleitorais, pois têm a capacidade de capturar a atenção do eleitor em momentos em que ele não aguarda uma campanha política (Aldé e Dias, 1998; Albuquerque, 1998). No entanto, a especificidade desse material recomenda um estudo separado.

7 Entendemos que o discurso de uma campanha ou de um candidato se constrói fundamentalmente em complexas relaçôes que envolvem os públicos desses discursos e seus adversários políticos (Albuquerque, 2011; Mendonça e Santos, 2009). Partimos, pois, de alicerces bakhtinianos, que asseveram a conformação interacional e intertextual dos discursos. No entanto, nesse texto inicial, apenas mapeamos o discurso de Dilma. A ideia é prosseguir a pesquisa com o mapeamento de Serra e Marina para realizar os devidos cruzamentos. 
8 Por segmentos, entendem-se fragmentos do programa que têm autonomia discursiva, como definido por Afonso Albuquerque (1999) e endossado por Figueiredo e Aldé (2010). Encontrar tais fragmentos é sempre uma operação difícil, já que "os programas do HGPE se valem frequentemente de uma estrutura complexa, articulando em um mosaico uma série de pequenas mensagens distintas entre si” (Albuquerque, 1999, p. 30).

9 A esse respeito ver Porto (2004) e Mendonça e Simões (2012)

10 Cabe ressaltar que definimos esses quadros em termos gerais e que existem debates muito mais complexos dentro e entre cada uma dessas vertentes. Para um mapeamento sintético,ver Dietz (2003).

11 Fazemos menção aqui a uma das citações mais reproduzidas por pesquisadores que se dedicam à análise de enquadramento: "enquadrar é selecionar alguns aspectos da realidade percebida e ressaltá-los em um texto comunicativo, promovendo uma definição particular de um problema, uma interpretação causal, uma avaliação moral e/ou um tratamento recomendado" (Entman, 1993, p. 52).

12 Cabe ressaltar que o discurso da igualdade envolve debates mais complexos do que os apresentados aqui, incluindo desdobramentos que têm sido classificados como feminismo da diversidade ou teorias que buscam respostas mais amplas para questôes como cidadania e justiça (Fraser, 2003; Young, 1990; Okin, 1989; Dietz, 1987). Debates neste campo reconhecem que os sistemas de opressão que atuam sobre as hierarquias de gênero também cruzam os eixos de raça, classe, sexualidade, entre outros (Crenshaw, 1991, 2002; Collins, 1998).

13 É curioso observar, contudo, que o narrador dos programas da candidata não teve o mesmo cuidado, utilizando-se sempre de substantivos masculinos para se referir indiscriminadamente a homens e mulheres.

14 Para uma breve explicação do uso recente de “@” para determinar uma categoria "genérica" quando se deseja referir tanto a mulheres como a homens, ver site do Centro Feminista de Estudos <http://www.cfemea. org.br/index.php?option=com_content\&view=article \&id $=2830 \&$ Itemid $=117>$.

15 De forma sucinta, um dos aspectos que fundamenta o debate é o fato de que feministas criticam a perspectiva igualitária por trabalhar dentro de um enquadramento que aceita uma lógica dicotômica. $\mathrm{O}$ discurso da diferença também tem sido criticado por operar com o binário homem e mulher, apenas invertendo a lógica da valorização. Nesse quadro, a perspectiva da diferença não rompe com a construção social da desigualdade, fortalecida ao longo dos anos a partir desses sistemas binários. Nancy Fraser (1997), por exemplo, destaca que os discursos de igualdade e de diferença devem ser vistos como estratégias complementares.

16 O programa do HGPE de Dilma conta apenas com um narrador masculino. Segundo Sapiro, Walsh, Strach e Hennings (2009, p. 108), campanhas televisivas continuam reforçando papéis tradicionais de gênero ao se utilizar mais de vozes masculinas. Contudo, na campanha de Dilma, nota-se uma opção delibera$\mathrm{da}$, na medida em que há duas apresentadoras (e apenas um apresentador), além da inclusão sistemática de relatos de mulheres comuns.

17 A esse respeito, ver Mantovani (2011).

18 De acordo com Lula Pires (2011, p. 141), "No dia 7 de março de 2008, por ocasião da assinatura de ordem de início de obras do Programa de Aceleração do Crescimento (PAC) na comunidade do Complexo do Alemão, na cidade do Rio de Janeiro, Dilma Rousseff recebe de Lula o epíteto de mãe do PAC: 'A Dilma é uma espécie de mãe do PAC; é ela que cuida, é ela que acompanha, é ela que vai cobrar junto com o Márcio Fontes [ministro das Cidades] se as obras estão andando ou não estão andando' (Lula e Kamel, 2009, p. 247)".

19 Em diversos programas do primeiro turno, Olívio Dutra dá um depoimento sobre Dilma. No segmento que retrata sua biografia, Dutra afirma que "Dilma tem uma sensibilidade à flor da pele e tem também uma objetividade [...]" [HGPE 17/8 tarde, repetido em 19/8 tarde, 14/9 noite, 16/9 tarde, 23/09 noite].

$20 \mathrm{O}$ trecho inicial desse segmento já fora veiculada em $8 / 10$.

21 "Foram esses valores que definiram e guiaram a nossa prática social. No combate à pobreza, na distribuição de renda, na diminuição das desigualdades e na busca de oportunidades para todos. É esse Brasil que construímos e vamos continuar construindo em nome das crianças, dos jovens, dos adultos e idosos de todo o Brasil" [HGPE, 12/10 noite].

22 Esses programas fazem parte de um segmento que discorre sobre segurança e combate às drogas. Em um deles Dilma conversa com várias mulheres e mães que fazem parte do grupo Mulheres da Paz no Rio Grande do Sul.

23 Cláudia Costa (2002) explica essa abordagem ao ilustrar como o feminismo foi capaz de edificar uma especificidade do feminino, fabricando uma identidade 
de gênero, sem transformá-la em uma posição nominalista. De acordo com Costa, foi justamente isso que impediu a celebração cética de um feminismo sem mulheres deduzido de perspectivas desconstrucionistas.

24 Para usar dois exemplos norte-americanos, lembremos-nos de Sarah Palin e Hilary Clinton. A primeira é vista como incompetente, a segunda como não suficientemente feminina. $\mathrm{Na}$ interessante análise de Susan Carroll (2009) sobre a campanha de Hillary Clinton, a autora ressalta que o tema de "experiência" se tornou o eixo central da sua campanha como forma de enfrentar os estereótipos de gênero. Porém ao focar detalhadamente os anos de experiência na política, a campanha de Hillary cedeu o tema de "mudança" a Obama. Hillary Clinton passou então a ser associada ao status quo.

\section{BIBLIOGRAFIA}

ALBUQUERQUE, A. (1995), "Política versus televisão: o horário gratuito na campanha presidencial de 1994". Comunicação \& Política, 1 (3): 49-54.

. (1998), "Spots políticos: americanização da propaganda política brasileira?”. Textos de Cultura e Comunicação, 39: 113-129.

. (1999), Aqui você vê a verdade na tevê: a propaganda politica na televisão. Dissertação de mestrado, Niterói, RJ, UFF.

(2001), "Em nome do público: jornalismo e política nas entrevistas dos presidenciáveis ao Jornal Nacional'. Trabalho apresentado no XX Encontro Anual da Compós, Porto Alegre, 14-17 jun.

ALBUQUERQUE, A.; STEIBEL, Fabro \& CARNEIRO, C. M. Z. (2008), "A outra face do horário gratuito: partidos e eleiçōes proporcionais na televisão". Dados, 51 (2): 459-487.

ALDÉ, A. \& DIAS, Heloisa. (1998), "Intervalo surpresa: spots eleitorais na campanha municipal de 1996". Comunicação \& Política, 5 (1): 83-100.

ALMEIDA, Jorge. (1999), "A conquista do lugar de fala e a fala fora do lugar nos discursos de FHC e Lula sobre o real", in Antônio Albino Canelas Rubim, Ione Maria Ghislene Bentz e José Milton Pinto (orgs.), Práticas discursivas na cultura contemporânea. São Leopoldo, Editora Unisinos/Compós, pp. 69-91.

ALMEIDA, Jorge. (2002), Marketing politico, hegemonia e contra hegemonia. São Paulo, Fundação Perseu Abramo/Xamã.

BANWART, Mary Christine. (2010), "Gender and candidate communication: effects of stereotypes in the 2008 elections". American Behavioral Scientist, 54: 265-283.

BATESON, Gregory. (2002), "Uma teoria sobre brincadeira e fantasia", in B. T. Ribeiro e P. M. Garcez (orgs.), Sociolinguistica interacional, 2 ed. rev. e ampl, São Paulo, Loyola.

BUTLER, Judith. (2000), "Subjects of sex/gender/ desire", in Simon During (ed.), The cultural studies reader, Londres: Routledge, pp. 340-353.

CARROLL, Susan J. (2009), "Reflections on gender and Hillary Clinton's presidential campaign: the good, the bad, and the misogynic". Politics \& Gender, 5: 1-20.

CARVALHO, Rejane M. V. A. (1998), "A esquerda do padrão midiático publicitário da política: a campanha de Maria Luiza (PT) à prefeitura de Fortaleza em 1985". Texto apresentado no XXII Encontro Anual da Anpocs, Caxambu, 27-31 out.

CHAIA, Vera. (2004), "Eleiçōes no Brasil: o medo como estratégia política", in Antonio Albino Canelas Rubim (org.), Eleiçôes presidenciais em 2002 no Brasil: ensaios sobre mídia, cultura e política. São Paulo, Hacker Editores, vol. 1, pp. 29-52.

(2004), "Um mago do marketing político", in Miguel Chaia e Ana Amélia da Silva (orgs.), Sociedade, cultura e politica, 2 ed., São Paulo, Educ, vol. 1, pp. 517-562.

CHILDS, S. (2004), "A feminised style of politics? Women MPs in the House of Commons". The British Journal of Politics and International Relations, 6 (1): 3-19.

CHODOROW, N. (1989), Feminism and psychoanalytic theory. New Haven, Yale University Press.

(1999), The reproduction of mothering: psychoanalysis and the sociology of gender: with a new preface. Berkeley, University of California Press. 
COLLINS, Patricia Hill. (1998), "It's all in the family: intersections of gender, race and nation". Hypatia, 13 (3): 62-82.

COSTA, Cláudia de Lima. (2002), "O sujeito no feminismo: revisitando os debates”. Cadernos Pagu, 19: 59-90.

CRENSHAW, Kimberlé. (2002), “Documento para encontro de especialistas em aspectos da discriminação racial relativos ao gênero". Revista de Estudos Feministas, 10 (1): 171-188.

CRENSHAW, Kimberlé. (1991), "Mapping the margins: intersectionality, identity politics, and violence against women of color". Stanford Law Review, 43 (6): 1241-1299.

CHRISTOFOLETTI, R. \& WATZKO, R. C. (2009), "Mulheres negras nos jornais: exclusão, gênero e etnia”. Revista Famecos (online), 39: 98-104.

D'ANGELO, Paul. (2002), "News framing as a multiparadigmatic research program: a response to Entman". Journal of Communication, 52 (4): 870-888.

DIETZ, Mary. (1987), "Context is all: feminism and theories of citizenship". Daedulus, 116 (4): 1-24. (2003), "Current controversies in feminist theory". Annual Review of Political Science, 6: 399-431.

DOW, Bonnie \& TONN, Mari Boor. (1993), "Feminine style" and political judgment in the rhetoric of Ann Richards". Quarterly Journal of Speech, 79 (3): 286-302.

DRYZEK, John S. (2000), Deliberative democracy and beyond: liberals, critics, contestations. Nova York, Oxford University Press.

ELSHTAIN, Jean. (1981), Public man, private woman: women in social and political thought. Princeton, Princeton University Press.

ENTMAN, Robert M. (1993), "Framing: toward a clarification of a fractured paradigm". Journal of Communication, 43 (4): 51-58.

ESCOBAR-LEMMON, Maria \& TAYLORROBINSON, Michelle. (2005), "Women ministers in Latin American governments: when, where, and why?". American Journal of Political Science, 49 (4): 829-844.

FIGUEIREDO, Marcus. (2007), "Intenção de voto e propaganda política: efeitos da propaganda eleitoral”. Logos, 14: 9-20.
FIGUEIREDO, Marcus \& ALDÉ, A. (2010), “Intenção de voto e propaganda política: efeitos e gramáticas da propaganda eleitoral”, in Luis Felipe Miguel e Flávia Biroli (orgs.), Mídia, representação e democracia. Brasília/São Paulo, Hucitec, pp. 19-40.

FRASER, N. (1996), "Multiculturalism and gender equity: the U.S. 'difference' debates revisited". Constellations, 3 (1): 61-72.

. (1997), Justice interruptus: critical reflections on the "postsocialist" condition. Nova York, Routledge.

. (2003), "Social justice in the age of identity politics: redistribution, recognition, and participation", in N. Fraser e A. Honneth, Redistribution or recognition? A political-philosophical exchange, Londres/Nova York, Verso, pp. 7-109.

FRASER, N. \& HONNETH, A. (2003), Redistribution or recognition? A political-philosophical exchange. Londres/Nova York, Verso.

FUKS, M. \& PACHECO, Daniela. (2006), "Persuasão e deliberação sobre políticas públicas: a propaganda política no referendo das armas", in Magna Inácio, Raquel Novais e Fátima Anastasia (orgs.), Democracia e referendo no Brasil, Belo Horizonte, editora da UFMG, pp. 206-241.

GAMSON, William \& MODIGLIANI, André. (1989), "Media discourse and public opinion on nuclear power: a constructionist approach". American Journal of Sociology, 95 (1): pp. 1-37.

GILLIGAN, Carol. (1982), Uma voz diferente. Rio de Janeiro, Rosa dos Tempos.

GOFFMAN, Erving. (1986), Frame analysis: an essay on the organization of experience. Boston, Northeastern University Press.

GOMES, W. (2004), "A política da imagem", in - Transformaçôes da politica na era da comunicação de massa, São Paulo, Paulus, pp. 239-290.

HIRSCHMANN, Nancy. (2003), The subject of liberty: toward a feminist theory of freedom. Princeton, Princeton University.

HONNETH, Axel. (2003), Luta por reconhecimento: a gramática moral dos conflitos sociais. São Paulo, Editora 34. 
HTUN, Mala \& POWER, Timothy. (2006), "Gender, parties, and support for equal rights in the Brazilian Congress". Latin American Politics and Society, 48 (4): 83-104.

HUDDY, Leonie \& TERKILDSEN, Nayda. (1993), "The consequences of gender stereotypes for women candidates at different levels and types of office". Political Research Quarterly, 46 (3): 503-525.

JAMIESON, Kathleen Hall. (1995), Beyond the double bind: women and leadership. Nova York, Oxford University Press.

LOVENDUSKI, J. \& NORRIS, P. (2003), "Westminster women: the politics of presence". Political Studies, 51 (1): 84-102.

MANTOVANI, Denise. (2011), "Gênero e eleiçôes presidenciais: um estudo sobre a hegemonia da temática religiosa no debate eleitoral de 2011". Trabalho apresentado no IV Encontro da Compolítica, Rio de Janeiro, 13-15 abr.

MENDONÇA, R. F. \& SANTOS, D. B. (2009), "A cooperação na deliberação pública: um estudo de caso sobre o referendo acerca da proibição da comercialização de armas de fogo no Brasil". Dados, 52 (2): 507-542.

MENDONÇA, R. F. \& SIMŌES, P. (2012), "Enquadramento: diferentes operacionalizaçóes analíticas de um conceito". RBCS, 27 (79).

MIGUEL, L. F. (1996), "Sentidos do passado: nação, tradição e história na campanha eletrônica para o plebiscito de 21 de abril de 1993". Comunicação \& Política, 3 (2): 126-144.

(1998), "O campeão da união: o discurso de Fernando Henrique na campanha de 1994". Comunicação \& Politica, 5 (1): 49-82.

(2000), Mito e discurso político: uma análise a partir da campanha eleitoral de 1994. Campinas, SP, Editora da Unicamp/Imprensa Oficial. . (2000), "Teoria política feminista e liberalismo: o caso das cotas de representação". Revista Brasileira de Ciências Sociais, 15 (44): 91-102.

MIGUEL, L. F. (2010), "Apelos discursivos em campanhas proporcionais na televisão". Politica \& Sociedade, 16: 151-175.
MIGUEL, L. F. \& BIROLI, F. (2011), Caleidoscópio convexo: mulheres, politica e midia. São Paulo, Editora da Unesp.

MIGUEL, L. F. \& FEITOSA, F. (2009), "O gênero do discurso parlamentar: mulheres e homens na tribuna da Câmara dos Deputados". Dados, 52 (1): 201-221.

OKIN, Susan. (1989), Justice, gender and the family. Nova York, Basic Books.

PATEMAN, Carole. (1988), The sexual contract. Stanford, Standord University. (1990), "Does sex matter to democracy? A comment". Scandinavian Political Studies, 13 (1): 57-63.

PARRY-GILES, Shawn. (2000), "Mediating Hillary Rodham Clinton: television news practices and image making in the postmodern age". Critical Studies in Media Communication, 17 (2): 205-226.

PARRY-GILES, Shawn \& PARRY-GILES, Terry. (1996), "Gendered politics and presidential image construction: a reassessment of the 'feminine style". Communication Monographs, 63: 337-353.

PIRES, Teresinha Maria de C. C. (2011), "A construção da imagem pública política de Dilma Rousseff como "mãe do povo" brasileiro". $D e$ bates, 5 (1): 139-162.

PORTO, Mauro. (2004), "Enquadramentos da mídia e política", in A. A. C. Rubim (org), Comunicação e politica: conceitos e abordagens, Salvador, EDUFBA/Editora da Unesp, pp. 74-104.

PORTO, M. P. \& GURAZINA, L. S. (1999), "A política na TV: o horário eleitoral da eleição presidencial de 1994". Contracampo, 3: 5-33.

QUEIROZ, Adolpho Carlos Françoso. (2003), “A evolução do conceito de marketing político na America Latina". Anuário Unesco/Umesp de Comunicação Regional, 7: 130-153.

(org.). (2011), No espaço cênico de propaganda politica: mídia, comunicação e marketing politico nas campanhas presidenciais brasileiras. Taubaté, Papel Brasil.

REESE, Stephen D. (2007), "The framing project: a bridging model for media research revisited". Journal of Communication, 57 (1): 148-154. 
RUBIM, A. A. C. (2003), "As imagens de Lula president", in Antonio Fausto Neto e Eliseo Verón (orgs.), Lula presidente: televisão e política na campanha eleitoral, São Paulo/São Leopoldo, Hacker/Unisinos, pp. 43-64.

RUBIM, A. A. C.; KOPP, Juliana Borges \& ALBINATI, Mariana Luscher. (2004), "Mídia e eleições de 2002 na Bahia: estratégias no horário eleitoral”. Comunicação \& Política, 11: 106-134.

SAPIRO, Virginia; WALSH, Katherine Cramer; STRACH, Patricia \& HENNINGS, Valerie. (2009), "Gender, context and television advertising: a comprehensive analysis of 2000 and 2002 House Races”. Political Research Quarterly, 64: 107-119.

SPIVAK, Gayatri C. (2002), The post-colonial critic: interviews, strategies, dialogues. Nova York/ Londres, Routledge.

SQUIRES, Judith. (1999), Gender in political theory. Massachussetts, Blackwell.

STEINBERG, Marc W. (1998), “Tilting the frame: considerations on collective action framing from a discursive turn". Theory and Society, 27 (6): 845-872.

STOKES, Wendy. (2005), Women in contemporary politics. Cambrigde, Polity Press.

TAYLOR, Charles. (1997), As fontes do self. São Paulo, Edições Loyola.

VAN GORP, Baldwin. (2007), "The constructionist approach to framing: bringing culture back in”. Journal of Communication, 57 (1): 60-78.

VEIGA, Luciana F. (2003), "Em busca de razões para o voto: o uso que o eleitor faz da propaganda política”. Contracampo, 7: 183-208.

VEIGA, Luciana F. \& SANTOS, S. A. (2008), “O referendo das armas no Brasil: estratégias de campanha e comportamento do eleitor". Revista Brasileira de Ciências Sociais, 23: 59-77.

VENTURI, G. (1998), "Imagem pública, propaganda eleitoral e reeleição na disputa presidencial de 1998”. Comunicação \& Política, 3: 30-48.

WEAVER, David. (2007), "Thoughts on agenda setting, framing and priming". Journal of Communication, 57 (1): 142-147.

WEBER, Maria Helena. (1996), "Mídia e eleiçôes: relações (mal)ditas", in Antônio Fausto Neto e Milton José Pinto (orgs.), $O$ individuo e as mídias. Rio de Janeiro, Diadorim, pp. 11-29.

YOUNG, I. (1990), Justice and the politics of difference. Princeton: Princeton University Press. (2000), Inclusion and democracy.

Oxford: Oxford University Press. 


\section{DISCURSOS SOBRE O FEMININO: UM MAPEAMENTO DOS PROGRAMAS ELEITORAIS DE DILMA ROUSSEFF}

\section{Ricardo Fabrino Mendonça e Ana Carolina Ogando}

Palavras-Chave: Gênero; HGPE; Enquadramentos; Dilma Rousseff.

Este artigo busca discutir o modo como os programas do HGPE de 2010 da então candidata Dilma Rousseff mobilizaram a temática do feminino para articular noçôes sobre sua identidade e sobre a interface entre gênero e política. Para tanto, voltamo-nos, inicialmente, às teorias feministas com vistas a mapear quatro discursos recorrentes sobre gênero: (1) o discurso da igualdade; (2) a marcação da diferença; (3) a ética do cuidado; e (4) o desconstrucionismo. Com base nesses discursos, realizamos uma análise dos programas televisivos de Dilma, veiculados no primeiro e no segundo turnos. Por fim, discutimos as consequências da mobilização do discurso da ética do cuidado, indicando para uma tensão entre o perigo da essencialização pasteurizante e os potenciais do essencialismo estratégico.

\section{DISCOURSES ON THE "FEMININE": THE ETHICS OF CARE AND THE STRATEGIC ESSENTIALISM IN DILMA'S PRESIDENTIAL CAMPAIGN}

\section{Ricardo Fabrino Mendonça and Ana Carolina Ogando}

Keywords: Gender; Televised presidential campaigns; Ethics of care; Strategic essentialism; Dilma Rousseff.

This article seeks to discuss how the 2010 televised presidential campaign of the then candidate, Dilma Rousseff, mobilized feminine discourses in order to articulate notions on her identity and on the intersections between gender and politics. In order to do so, [we] the authors initially look to feminist theories in order to map four recurrent discussions on gender: (1) an equality approach; (2) a difference approach; (3) an ethics of care approach; and (4) a deconstructionist approach. Based on these discourses, we analyze Dilma's televised campaigns in the first and second rounds of the election. Finally, they discuss the consequences of mobilizing an ethics of care discourse, indicating tensions between the dangers of a pasteurizing essentialism and the potentials of strategic essentialism.

\section{DISCOURS SUR LE "FÉMININ": UNE MISE AU POINT DES PROGRAMMES ÉLECTORAUX DE DILMA ROUSSEFF}

\author{
Ricardo Fabrino Mendonça et Ana \\ Carolina Ogando
}

Mots-clés: Genre; Programmes télévises électoraux; Encadrements; Dilma Rousseff.

Cet article cherche à discuter la façon par laquelle les programmes télévisés de campagne de 2010 de Dilma Rousseff, alors candidate, ont mobilisé la thématique du féminin pour articuler des notions sur l'identité et sur l'interface entre genre et politique. Pour ce faire, nous nous tournons, initialement, vers les théories féministes, en vue de relever quatre discours récurrents sur le genre: (1) le discours de l'égalité; (2) l'indication de la différence; (3) l'éthique du soin; et (4) le déconstructionnisme. Ayant pour base ces discours, nous réalisons une analyse des programmes de télévision faits par Mme. Roussef sur les campagnes du premier et du second tours. $\grave{A}$ la fin, nous débattons les conséquences de la mobilisation du discours de l'éthique du soin, qui indiquent une tension entre le danger de l'essentialisation pasteurisante et les potentiels de l'essentialisme stratégique. 